\title{
RECENT UPDATED ASPECTS OF COLICINS OF ENTEROBACTERIACEAE
}

\author{
Luciana Cursino $^{1}$; Jan Šmarda ${ }^{2}$; Edmar Chartone-Souza ${ }^{1}$; Andréa M.A. Nascimento ${ }^{1 *}$ \\ ${ }^{1}$ Departamento de Biologia Geral, Universidade Federal de Minas Gerais, Belo Horizonte, MG, Brasil. ${ }^{2}$ Department of Biology, \\ Faculty of Medicine, Masaryk University, Brno, Czech Republic.
}

Submitted: August 20, 2001; Returned to authors for corrections: January 08, 2002; Approved: July 26, 2002

\section{MINI-REVIEW}

\begin{abstract}
The colicins are protein compounds produced by, and active against, Escherichia coli and others members of Enterobacteriaceae family. At least 34 different colicins have been described and found to share an interesting number of features. In the present review we focus on the major characteristics of colicins of gramnegative bacteria and explore their production and practical applications.
\end{abstract}

Key words: colicins, Escherichia coli, genetics, evolution, ecology.

\section{INTRODUCTION}

The literature abounds with examples of antagonism between particular bacterial strains. In many instances the mediating agent is a bacteriocin. The bacteriocins are protein compounds produced by bacteria that inhibit or kill closed related species. Colicins are by far the best-characterized group of bacteriocins. They are produced by, and active against, Escherichia coli and others members of the Enterobacteriaceae family $(79,98)$.

At least 34 different colicins have been described, 21 of them in greater detail (Table 1) and they share an intriguing number of features. Under conditions of stress a fraction of colicinogenic bacteria are induced to produce colicin proteins. The type of stress causing the inductive activity needs to be better characterized. The release of colicins is in itself not always lethal to the producing cell. The colicinogenic bacteria are specifically protected against the colicins they produce. In addition, colicin gene clusters are plasmid encoded $(82,98)$. A number of different applications have been suggested for colicins due to their broad spectrum of action. Examples of this kind include the control of diarrheal diseases caused by enteropathogenic bacteria, as food preservatives and others $(61,98)$. In this review we focus on the most important aspects of these intriguing proteins called colicins.

\section{PROTEIN STRUCTURE, RECEPTORS AND TRANSLOCATION ROUTES}

All colicins show the same type of organization, coherent with their mechanism of action. The standard functional domain sequence of all colicin molecules is from N' (amino) to C' (carboxy) terminus. Their structure comprises three distinct domains: (A) a domain involved in recognition of specific receptors, (B) a domain involved in translocation, and (C) a domain responsible for their lethal activity, with a molecular mass of 30 to $70 \mathrm{kDa}(5,50)$.

To exert their action, colicins must cross a physical barrier, the outer membrane with lipopolysaccharide molecules on the outer surface of its bilayer and its small pores, and be taken up by the sensitive cells (5). Thus, the colicins developed a mechanism of parasitism of multiprotein system used by sensitive cell for important biological functions. These proteins include porins (OmpF, OmpA and OmpC), vitamin B12 (BtuB), siderophore and nucleoside (Tsx) receptors, (Table 1) as well as the multiprotein systems that contribute these proteins (49).

Two different but homologous translocation systems have been described, the Ton and the Tol systems (Fig. 1). The Ton translocation system is formed by TonB and two other proteins, ExbB and ExbD, which are clustered on the E. coli chromosome $(2,106)$. The components of the Tol translocation system are

*Corresponding author. Mailing address: Av. Antônio Carlos, 6627, Departamento de Biologia Geral - Instituto de Ciências Biológicas, Universidade Federal de Minas Gerais. 31270-901, Belo Horizonte, MG, Brasil. Fax: (+5531) 3499-2567. E-mail: amaral@icb.ufmg.br. 
Table 1. The most important types of colicins and other bacteriocins of the Enterobacteriacea family. Aadapted from Šmarda and Šmajs (98).

\begin{tabular}{|c|c|c|c|c|c|c|}
\hline Colicin & $\begin{array}{c}\text { Receptor/ } \\
\text { Assisting } \\
\text { protein }\end{array}$ & $\begin{array}{c}\text { Translocation } \\
\text { route }\end{array}$ & $\begin{array}{l}\text { Mechanism of } \\
\text { Action }\end{array}$ & $\begin{array}{l}\text { Colicin } \\
\text { Molecular } \\
\text { weight }\end{array}$ & $\begin{array}{l}\text { Original } \\
\text { producer } \\
\text { strain }\end{array}$ & References \\
\hline A & $\mathrm{BtuB} / \mathrm{OmpF}$ & TolA, B,Q,R, & pore formation & $62.989^{+}$ & $\begin{array}{l}\text { Citrobacter } \\
\text { freundii }\end{array}$ & $\begin{array}{l}30 \\
59\end{array}$ \\
\hline B & FepA & TonB/ExbB, D & pore formation & 54.732 & E. coli & $\begin{array}{l}30 \\
87\end{array}$ \\
\hline $\mathrm{D}$ & FepA & TonB/ExbB, D & translation block & 74.688 & E. coli & $\begin{array}{l}30 \\
84\end{array}$ \\
\hline E1 & BtuB/TolC & TolA, B,Q,R, & pore formation & 52.279 & E. coli & $\begin{array}{l}30 \\
14\end{array}$ \\
\hline E2 & $\mathrm{BtuB} / \mathrm{OmpF}$ & TolA, B,Q,R, & DNA endonuclease & 61.561 & $\begin{array}{c}\text { Shigella } \\
\text { sonnei }\end{array}$ & $\begin{array}{l}30 \\
17\end{array}$ \\
\hline E3 & $\mathrm{BtuB} / \mathrm{OmpF}$ & TolA, B,Q,R, & $\begin{array}{c}\text { rRNA } \\
\text { endonuclease }\end{array}$ & 57.960 & E. coli & $\begin{array}{l}30 \\
42\end{array}$ \\
\hline E4 & $\mathrm{BtuB} / \mathrm{OmpF}$ & TolA, B,Q,R, & $\begin{array}{c}\text { rRNA } \\
\text { endonuclease }\end{array}$ & $\mathrm{ND}$ & E. coli & $\begin{array}{l}37 \\
73\end{array}$ \\
\hline E5 & $\mathrm{BtuB} / \mathrm{OmpF}$ & TolA, B,Q,R, & translocation block & $\mathrm{ND}$ & E. coli & $\begin{array}{l}57 \\
48\end{array}$ \\
\hline E6 & BtuB/OmpF & TolA, B,Q,R, & $\begin{array}{c}\text { rRNA } \\
\text { endonuclease }\end{array}$ & 58.011 & E. coli & $\begin{array}{c}57 \\
3\end{array}$ \\
\hline E7 & BtuB/OmpF & TolA, B,Q,R, & DNA endonuclease & 61.349 & E. coli & $\begin{array}{l}57 \\
13\end{array}$ \\
\hline E8 & $\mathrm{BtuB} / \mathrm{OmpF}$ & TolA, B,Q,R, & DNA endonuclease & 70.000 & E. coli & $\begin{array}{c}18 \\
104\end{array}$ \\
\hline E9 & $\mathrm{BtuB} / \mathrm{OmpF}$ & TolA, B,Q,R, & DNA endonuclease & ND & E. coli & $\begin{array}{l}18 \\
43\end{array}$ \\
\hline G & Fiu & TonB/ExbB, D & membrane lysis ${ }^{\mathrm{ND}}$ & 5.500 & E. coli & $\begin{array}{c}30 \\
7\end{array}$ \\
\hline $\mathrm{H}$ & Fiu & TonB/ExbB, D & membrane lysis ${ }^{\mathrm{ND}}$ & 100 & E. coli & $\begin{array}{c}30 \\
7\end{array}$ \\
\hline Ia & Cir & TonB/ExbB, D & pore formation & 69.406 & E. coli & $\begin{array}{l}30 \\
46\end{array}$ \\
\hline $\mathrm{Ib}$ & Cir & TonB/ExbB, D & pore formation & 69.963 & Sh. sonnei & $\begin{array}{l}30 \\
46\end{array}$ \\
\hline $\mathrm{J}_{\mathrm{S}}$ & ND & ND & ND & 46.000 & Sh. sonnei & $\begin{array}{c}1 \\
97\end{array}$ \\
\hline $\mathrm{K}$ & Tsx/OmpF, A & TolA, B,Q,R, & pore formation & 59.6111 & Sh. sonnei & $\begin{array}{l}30 \\
68\end{array}$ \\
\hline $\mathrm{L}^{\square}$ & ND/OmpA & TolA, Q, ND & pore formation & 45.000 & $\begin{array}{c}\text { Serratia } \\
\text { marcescens }\end{array}$ & $\begin{array}{l}39 \\
27\end{array}$ \\
\hline $\begin{array}{c}\text { Bacteriocin } \\
28 \mathrm{~b}\end{array}$ & $\begin{array}{l}\text { ND/OmpA, } \\
\text { F, LPS }\end{array}$ & TolA, B,Q,R, & Pore formation & 47.462 & $\begin{array}{c}\text { Serratia } \\
\text { marcescens }\end{array}$ & 107 \\
\hline M & FhuA & TonB/ExbB, D & $\begin{array}{l}\text { Inhibition of } \\
\text { murein synthesis }\end{array}$ & 29.453 & E. coli & $\begin{array}{l}29 \\
64\end{array}$ \\
\hline $\mathrm{N}$ & $\begin{array}{c}\text { OmpF/OmpC, } \\
\text { Phoe }\end{array}$ & TolA, Q,R, & pore formation & 41.696 & E. coli & $\begin{array}{l}36 \\
72\end{array}$ \\
\hline Q & Cir & TonB/ExbB, D & ND & ND & E. coli & 93 \\
\hline S1 & Cir & TonB/ExbB, D & pore formation & ND & Sh. boydii & $30 / 89$ \\
\hline S4 & SrfND/OmpF & TolA, B,Q, R, & pore formation & ND & E. coli & $30 / 89$ \\
\hline $\mathrm{U}$ & $\begin{array}{c}\text { OmpA/OmpF, } \\
\text { LPS }\end{array}$ & TolA, B,Q,R, & pore formation & 66.289 & Sh. boydii & $40 / 90$ \\
\hline 5 & Tsx/TolC & TonB/ExbB, D & pore formation & 53.137 & E. coli & $8 / 67$ \\
\hline 10 & Tsx/TolC & TonB/ExbB, D & pore formation & 53.342 & E. coli & 66 \\
\hline Pesticin I & FyuA & TonB/ExbB, D & hyidrolysis of murein & 40.043 & Yersinia pestis & $6 / 69$ \\
\hline Cloacin DF13 & IutA/OmpF & TolA, Q,R & rRNA endonuclease & 59.283 & Enterobacter cloacae & $101 / 105$ \\
\hline V (MIcrocinV) & Cir/TolC & CvaA, CvaB, CvaA* & pore formation & 9 & E. coli & 41 \\
\hline
\end{tabular}

+Molecular weight (kDa); ND not determined; LPS lipopolysaccharide; ' Colicin L and Bacteriocin $28 \mathrm{~b}$ are very similar, if not identical (35). 


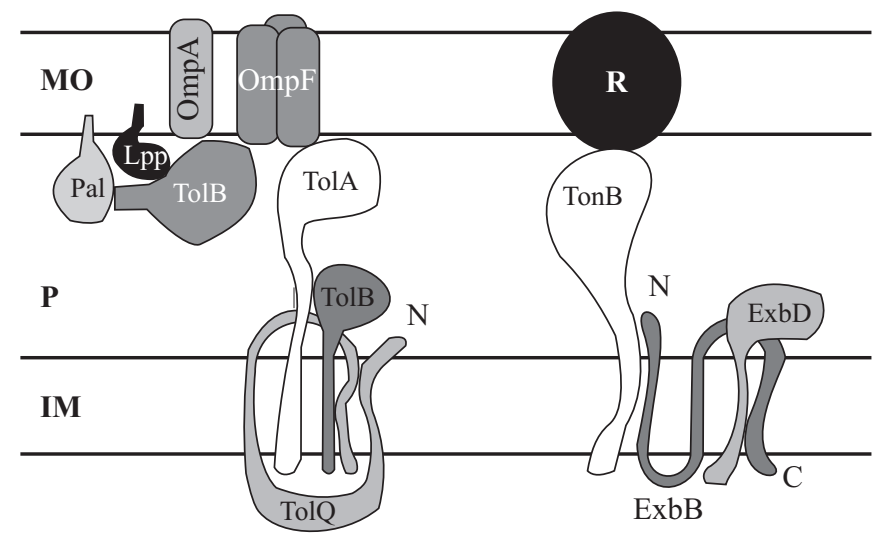

Figure 1. TonB and Tol-Pal translocation systems. OM. outer membrane, P. periplasmic space, IM. inner membrane, R. TonBdependent receptor, C. C-terminus and N. N-terminus (50).

TolQ, TolR, TolA, TolB, and Pal and their genes are clustered also on the E. coli chromosome (70).

\section{MECHANISM OF ACTION}

Colicins kill sensitive bacteria in three main and distinct ways (Fig. 2). The most frequent mechanism is the formation of ion channels in the plasma membrane (pore formation), resulting in membrane depolarization $(5,98)$. The opening of the pore also induces a phosphate and sometimes $\mathrm{K}^{+}$efflux, which leads to depletion of cytoplasmic ATP (50). Less frequent is the nuclease activity of colicins, which can be directed against the chromosomal DNA (acting as a nonspecific DNA endonuclease) or a specific endonuclease against 16S-rRNA. The least frequent is degradation, catalyzing the hydrolisis of the $\beta-1,4$ bond between $\mathrm{N}$-acetyl glucosamine and $\mathrm{N}$-acetylmuramic acid in the glycan backbone of the bacterial cell wall or inhibition of synthesis of wall peptidoglycan or murein inducing the formation of spheroplasts and consequently, cell lysis $(47,98)$. Interestingly, the mechanism of inhibition of murein synthesis and hydrolysis is quite similar to betalactamic antibiotics and lisozyme action.

The mode of action of many colicins has not been clarified. However the colicin A (pore forming) and colicin E groups (nucleases) are the most thoroughly understood, as shown in Figs. 3 and 4, although the molecular events of translocation and final interaction with a particular cellular target are not known for most colicins $(19,49)$.

\section{GENETIC FEATURES, COLICIN SYNTHESIS, INDUCTION AND CELL DEATH}

The synthesis of colicins is coded by genes on the socalled Col plasmids which may or may not be conjugative or even able to mobilize the transfer of genes encoding for antibiotic resistance and other genes encoding virulence factors of uropathogenic E.coli $(16,32)$. The pCol plasmids vary widely in size, commonly from $6.6 \mathrm{~Kb}$ (pColE1) to $94 \mathrm{~Kb}(\mathrm{pColH})$; however plasmids smaller than $5.5 \mathrm{~Kb}$ and plasmids larger than $94 \mathrm{~Kb}$ have been detected (98).

The basic genetic structure of colicin consists of a gene cluster that carries at least two, usually three genes, the colicin structural gene ( $c o l$ or cea in the pColE1), followed by the gene (imm) for the structure of the immunity protein and finally the gene (kil) encodes for the lysis protein or bacteriocin release protein (BRP).

Colicin production is induced by DNA-damaging agents, or environmental factors such as increasing population density and nutrient depletion (65). E. coli cells containing the Col plasmid normally synthesize the bactericidal colicin at low levels, but exposure to DNA-damaging agents such as UV irradiation or mitomycin C induces high levels of synthesis (44). The factor responsible for this induction is the bacterial "SOS system of DNA repair" which causes RecA proteinase activation and consequent inactivation of Lex A protein, which is a repressor of many DNA repair genes and also of plasmid genes for colicin synthesis $(56,99)$. Under standard, but unknown, conditions, colicin synthesis is switched off in most cells of the population; it occurs only in a small part of the population as a result of a random activation of the "SOS system of DNA repair" (98). Other mechanisms of colicin synthesis have been described such as nonspecific catabolic repression and mRNA regulation by "stringent response" $(55,86)$.

Colicin release into extracellular medium requires the expression and activity of a so-called BRP or lysis protein (108).

The lytic protein is a small lipoprotein that activates the endogenous outer membrane phospholipase A which is important for the permeabilization of the cell envelope (lysis) and death of the producer bacteria (21). However, some colicin gene clusters do not contain a gene kil (lysis protein) and the mechanism by which these colicins reach extracellular environment is unclear.

\section{IMMUNITY TO COLICINS}

Colicinogenic bacteria are protected against colicin molecules they produce. This specific protection is provided by an immunity protein that interacts specifically with the $\mathrm{C}$ terminus domain of the colicin protein, rendering it inactive (75). The immunity proteins that bind in the cytoplasm to the colicins with nucleasic activities such as E2 and E9 are released as an equimolar colicin-immunity protein complex into the extracellular medium. The immunity proteins of the colicins with pore-forming activity such as Ia and Ib are found and active in the cytoplasmic membrane, and these colicins are released without bound immunity proteins (12). 

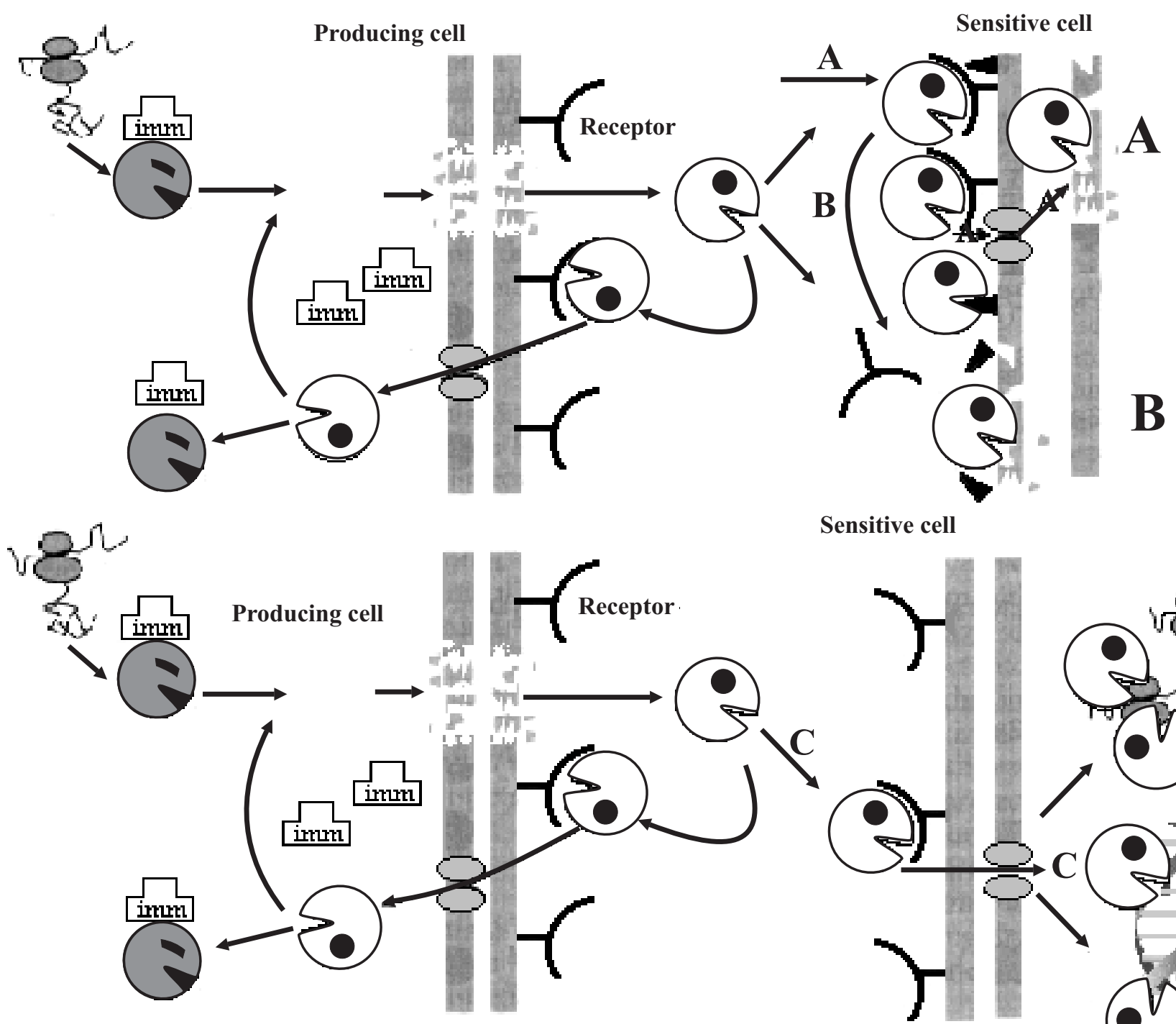

Sensitive cell

Figure 2. Schematic representation of the mechanism of action of colicins. (A) pore- forming colicins, (B) colicin that cause hydrolysis of peptidoglycan $(\mathbf{C})$ nucleases. The colicins are produced and their binding to their specific immunity protein -Imm (white hat) became inactive (dark gray circle). Colicins could be released by cell lysis in their active form (white circle). In the extracellular medium this colicin form could bind to specific receptor in the sensitive cells and translocate (light gray flattened circles) through the cytoplasm and exert its specific mode of action(A), (B) or (C). However, producing cells could recognized the active form of colicin, but immediately after their translocation it would be inactivated by binding to the immunity protein. Adapted from Baba and Scheneewind (4).

Expression of the immunity genes may or may not be subject to the "SOS system of DNA repair" control. The immunity genes with the same transcription polarity as the colicin genes are controlled by the "SOS system of DNA repair", whereas immunity genes transcribed in opposite orientation have their own, usually weak, promoter (10).

\section{COLICIN ECOLOGY}

From an ecological point of view, colicins are anticompetitor molecules (23). Although research on colicins has generated a wealth of information in terms of molecular genetics, mode of action and application, little is known about the natural ecology 

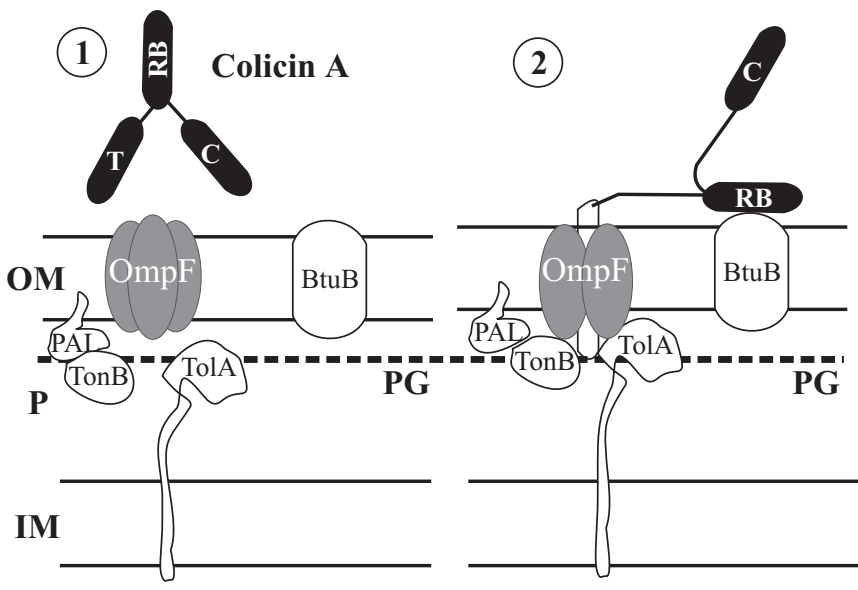

(3)
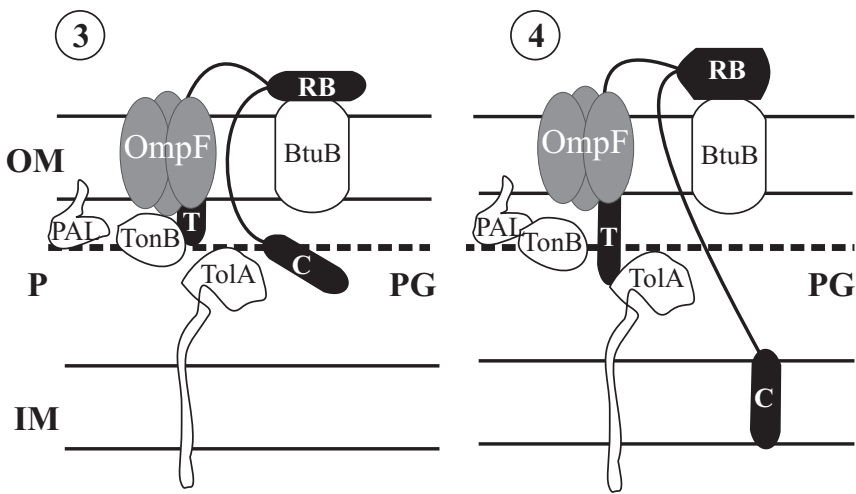

Figure 3. Mechanism of action and translocation of colicin A. $\mathbf{O M}$, outer membrane, $\mathbf{P}$, periplasmic space, $\mathbf{I M}$, inner membrane, $\mathbf{C}$, colicin activity domain; PG, peptidoglycan; RB, receptor binding domain, $\mathbf{T}$, translocation domain. (1) Colicin A with its three domains (2) Colicin A after binding to its receptor (BtuB) is unfolded, allowing the translocation domain (T) to access the OmpF porin. (3) On the inner surface of the outer membrane the $\mathrm{T}$ domain interacts with TolB protein, which then cannot interact with the Pal protein. (4) These actions lead to a nonstabilization of peptidoglycan and allow the activity domain of colicin A (C) to penetrate the inner membrane, resulting in its depolarization by pore forming. The opening of the pore also induces a phosphate and sometimes $\mathrm{K}^{+}$efflux which leads to depletion of cytoplasmic ATP (50).

of colicins and the role it plays in the bacterial ecology (24). The production of substances that exhibit antimicrobial characteristics such as colicins is one of the numerous mechanisms that enable bacteria to respond to environmental challenges (11). It apparently plays a role in competitive interactions between members of a microbial community (82).

Although colicin production is widespread, colicins are assumed to be of greater significance in intra- rather than

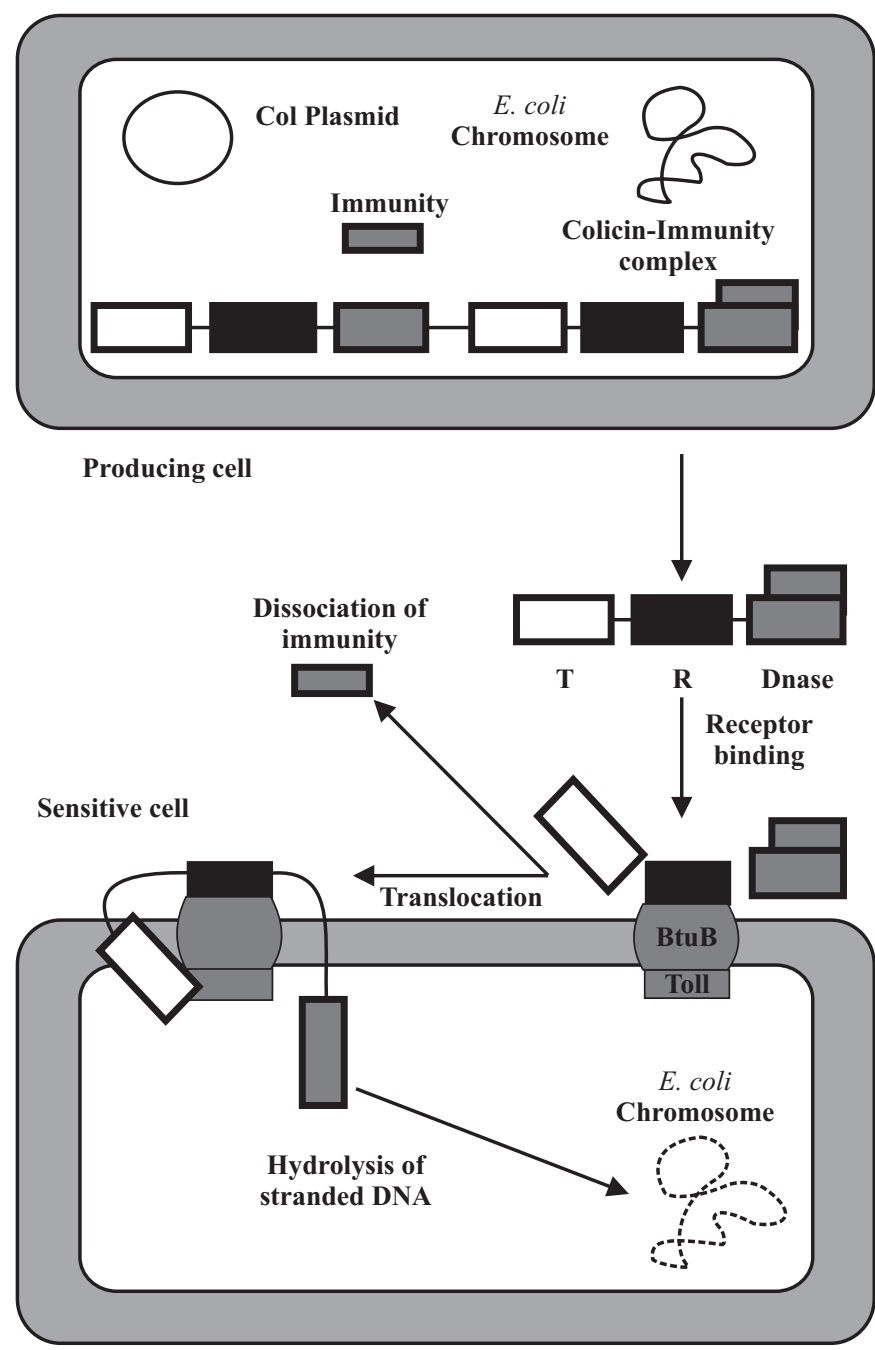

Figure 4. Mechanism of action of $\mathrm{E}$ group colicins. T, translocation domain, $\mathbf{R}$, receptor-binding domain, Dnasecolicin activity domain. Co-expression and rapid association of the immunity protein (small dark gray rectangle) with its cognate colicin confers protection to cells harboring the $\mathrm{col}$ plasmid both during colicin production and after its release. The $\mathrm{R}$ domain (black rectangle) binds to its receptor (BtuB) on the outer membrane. Probably at this time, the immunity proteins dissociate from the complex and then translocate their activity domain-Dnase (dark gray rectangle) with the help of Tol proteins. Nonspecific cleavage of double-stranded DNA occurs in the cytoplasm (Adapted from Cramer et al.) (19).

interspecies competitive interactions. This concept results from observations suggesting that a colicin produced by one species is usually not effective against strains from different species (28). 


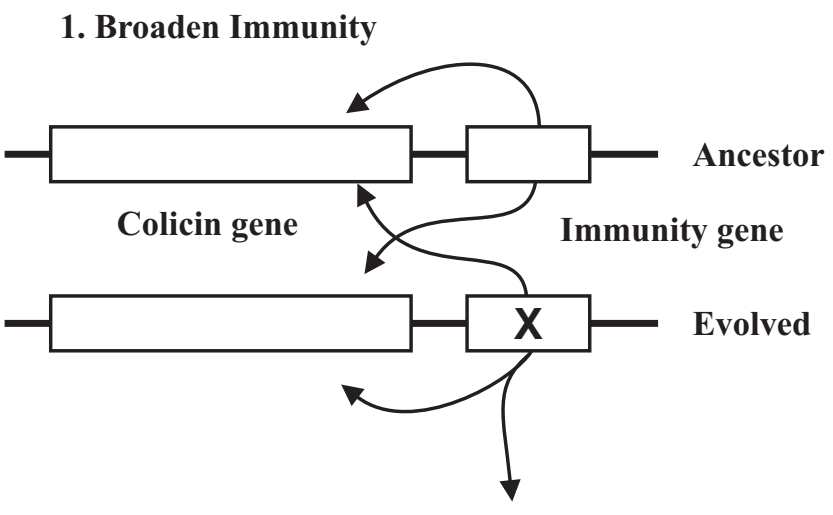

\section{Colicin Super killer}

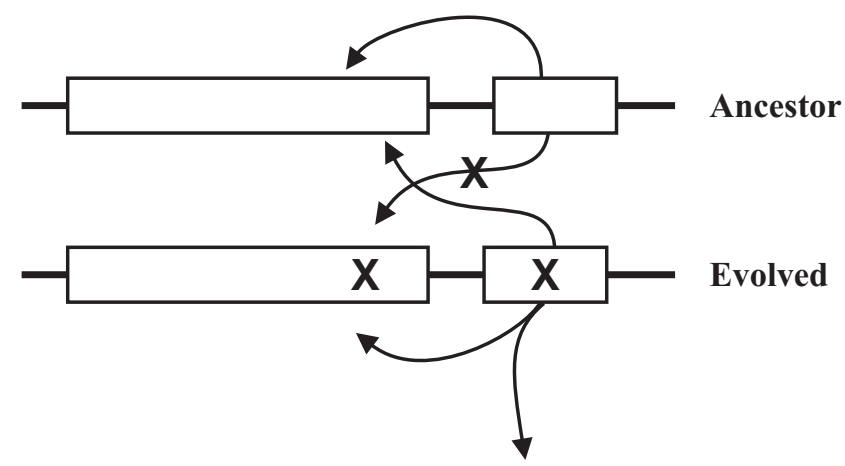

Figure 5. Schematic representation of the diversifying selection hypothesis. 1, First of all, there is generation of a broadened immunity in the evolved colicin gene cluster due to the starred point mutation $(\mathrm{X})$ in the immunity gene 2, After that, there is generation of a super colicin killer due to the starred point mutation in the immunity-binding region of the colicin gene. The arrows indicate the immunity relationships between the ancestor and evolved colicin gene clusters. An arrow from one immunity gene (rectangle on right) to one colicin gene (rectangle on the left) indicates that the encoded immunity will protect against the encoded colicin protein (79).

The best evidence for the ecological role of the colicins is the high frequency at which natural colicinogenic strains are encountered (75). The frequency of colicinogeny in E.coli strains is usually reported to be $24-45 \%$ (9). Little is known about the factors that determine the frequency of colicinogeny in natural populations $(38,88)$. However, Pugsley $(74)$ reported that more than $30 \%$ of lactose-fermenting gram-negative bacteria isolated from the River Seine produced one or more colicins, which were active against $E$. coli $\mathrm{K} 12$, a standard colicin indicator strain. Surprisingly, $98 \%$ of these strains were susceptible to classic antibiotics (76).

Studies suggest that colicinogeny is more frequent among pathogenic than commensal isolates and that it is more prevalent among humans isolates $(50 \%)$ than animal isolates $(16 \%)$ $(80,109)$.

It seems unclear whether colicinogeny itself is an independent pathogenic factor or whether it is an associated marker of other virulence factors. However, several virulence factors including synthesis of aerobactin, alpha-haemolysin and P-fimbriae are known to be associated with some colicins and may account for this association $(22,60,63)$.

The increased virulence of colicinogenic strains, in particular of those producing colicin $\mathrm{V}$ (has been now classified as a microcin V) might be due to these virulence determinants since colicin $\mathrm{V}$ itself does not seem to act as a pathogenic determinant, though a report has been shown that colicin $\mathrm{V}$ is directly involved in pathogenesis. $(63,111)$.

Recent data reported by Šmarda and Obdrzálek (94) showed that $41 \%$ of $E$. coli strains isolated from healthy humans in the Czech population produce colicins. The same incidence of colicinogenic producers has been found in the bowel of patients suffering of salmonelloses or malignant tumors of bowel. The incidence of haemolytic uropathogenic strains detected in these patients was only $22 \%$, whereas and incidence of $48 \%$ was found in the bowel of patients with Crohn's disease and the highest incidence, $56 \%$, was found in patients with ulcerative colitis.

\section{POPULATION ANALYSIS}

A number the theoretical models investigating the population dynamics of bacteriocin-producing bacteria have been described $(15,28,51)$. These models assumed the existence of a cost-benefit ratio. $(23,51)$. The sensitive cells are favored because they do not need to pay the cost associated with colicin production, i.e. the loss to the colicinogenic population due to colicin synthesis and subsequent cell lysis and the growth rate disadvantage resulting from the energetic costs imposed by colicin plasmid carriage (11). However, for the colicin-producing strain to invade a new habitat these cost must be exceeded by the advantage gained due to the fact that colicin production is determined by: the initial density of colicinogenic cells and by the rate at which sensitive cells are killed by the colicins, which in turn is determined by the amount of colicin released per lysed cell and by the rate at which colicin binds to sensitive cells $(15,28,51,82)$.

Some studies have suggested that the dynamics of these competitive interactions differ in different cells habitats $(15,81)$. It has been proposed that invasion of a sensitive population by a producer strain is predicted to be ineffective in a homogeneous, well-mixed medium, such as liquid culture, unless initial frequencies is high. This is due to the dilution of toxin in liquid culture and the cost of colicin production. On the other hand, it has been predicted that sensitive strains at low initial frequencies will not invade a colicin-producing population in a liquid culture 
due to the high levels of toxin present $(62,79)$. However, if there is a structure of the environment, such as a solid surface, and there is spatial heterogeneity in resource abundance, then a stable polymorphism of producer and sensitive strains can exist. In summary, sensitive strains will persist in poor habitats where the rate of resource competition is high, while producing strains will persist in rich habitats where resource competition is low and where they can take advantage of rich nutrient and energy sources for colicin production (28).

\section{COLICINS EVOLUTION}

Due to the large amount of information available, the colicins have served as a model to investigate the mechanism of evolution and diversification of bacteriocins $(26,83,103)$. Most of these studies has involved comparisons of DNA and protein sequences among colicin, immunity, and lysis genes, and encoded proteins to infer evolutionary relationship and molecular mechanism of diversification (79).

Riley (77) distinguished five classes of colicin proteins based on sequence comparisons. In the cited study she found a high similarity within class, except for colicin B, which shows similarities with colicin D (Fredericq, personal communication). The most interesting inference from the phylogenetic data of colicin protein is that this class of proteins represents a highly heterogeneous group (78).

Tan and Riley, (102) propose two different hypothetical models to explain the evolutive diversification of the colicins: positive selection and recombination.

The role of positive selection in colicin evolution has been proposed to explain an unusual pattern of divergence between two pairs of gene clusters (E3/E6 and E2/E9- nucleases). Comparisons of DNA sequence showed an apparent excess of synonymous substitutions (which alter a codon but not alter the specific amino acid) and nonsynonymous substitutions (which alter a codon as well as the specific amino acid) in the immunity portion, the immunity gene and the immunity binding region of the colicin gene.

To elucidate this phenomenon, a process of diversification was proposed. First of all, a point mutation occurs in the immunity gene of a colicin that confers a broadened immunity function. Those cells are immune to themselves, to their immediate ancestors, and to several other colicins (Fig. 5.1). This evolved colicin gene cluster will have an advantage over its ancestor in the presence of colicin and will be selectively retained in the population. Then, a second mutation may occur in the evolved colicin gene, resulting in a gene cluster that has a colicin to which its ancestor is no longer immune (Fig. 5.2).

A strain carrying this evolved colicin gene cluster will have a large and selective advantage. Hence, positive selection will drive this 'super killer' rapidly into the population, and repeated rounds of this form of diversification of immunity function will result in the accumulation of synonymous and nonsynonymous substitutions in the immunity portion (79).

In this case, positive selection can act to produce more and more diversity. Thus, the mechanism of 'super killer' appearance could be contributing to the enormous variation in E. coli DNA (5\%)- the highest diversity to be expected in a single species (58).

The second model, recombination, could explain why within pore-forming colicins the protein sequence similarity is low, rarely exceeding $40 \%$. Some findings have shown that in this group of colicins regions of the colicin gene sequence encoding rather precise functional domains have recombined to give rise to new colicins. Such recombination events occur between and within the groups of pore-forming colicins (79). Comparisons of DNA and protein sequence similarity of this colicin group have shown that they represent a highly divergent class of proteins and that they share a common ancestor. Thus, the process of diversification of pore-forming colicins is the result of numerous recombination events that play a role in selecting random functional domains of these colicins and generating novel types of colicins (80).

\section{COLICIN RESISTANCE}

There are two primary mechanisms that result in insensitivity of E.coli cells to the action of colicins, aside from the immunity mechanisms of the colicinogenic host: (a) resistance that evolved as an alteration by mutation or absence of a colicin receptor, and (b) tolerance that is related to absence of a functional colicin translocation system $(20,31,91,110,112)$.

Gordon et al. (33) revealed that more than $70 \%$ of natural isolates of E. coli were resistant to at least one colicin and 30\% of the isolates were resistant to three or more colicins. Loss of the receptor can confer resistance to all colicins that recognize a certain receptor. However, other receptor mutations have been described that provide specific resistance to a single colicin or a subset of colicins $(10,44,71)$.

It should be pointed out that the sensitivity of strains observed under natural conditions may change under in vitro conditions.

\section{ACTION OF COLICINS ON EUKARYOTIC CELLS}

Studies on the action of colicins on eukaryotic cells has been done since the 70's. Farkas-Himsley and Cheung (25) reported toxic effects of several bacteriocins produced by gramnegative bacteria, including colicins, on various eukaryotic cells. Šmarda et al. (95) detected inhibition of mouse fibroblasts L and human epithelial HeLa cells by colicin E3.

Saito and Watanabe (85) reported toxic effects of a colicin on the established mouse neoplastic L60T line. Many attempts were made to prove inhibitory effects of bacteriocins on mammalian cells, including tumor cells (92). 
Standard cells were shown to be less sensitive to colicins than tumor-transformed ones and malignant animal cells were more sensitive than human cells. Śmarda et al. (95) and Šmarda (92) described the inhibitory effects of colicins on eukaryotic cells in culture and also in vivo. In the first of these studies, several degrees of activity of a colicin towards various cells were found to be common, as later observed by others (54).

Recent reports, (94) showed that both colicins E1 and E3 were cytotoxic to oncogene v-myb-transformed chicken monoblasts. Chumchalova and Šmarda (personal communication) reported that colicins E1 and especially A inhibited 11 human tumor cell lines carrying determined mutations of the p 53 gene, while the parallel inhibition of a standard human fibroblast line was very low. The effect was cytotoxic. In the same systems, colicins E3 and U were shown to be ineffective. In addition, Oravec and Šmarda (personal communication) studied the effects of colicin E3 on solid HK-adenocarcinoma of mice in vivo. Tiny doses injected daily directly into subcutaneous nodes of the tumor reduced tumor weight by $61 \%$. Colicin E2 and $\mathrm{A}$ dramatically decreased the viability of three murine lymphoma cells lines by $40-58 \%$. Colicin A treatment of mice with transplanted LP-2 plasmocytoma prolonged their survival by $43 \%$.

\section{PRACTICAL APPLICATIONS OF COLICINS AND PERSPECTIVES}

A number of practical applications of colicins have been suggested, especially due to their antimicrobial properties. Different biological problems can be addressed using the colicin system (44). Interest in natural products rather than man-made chemicals should lead to further opportunities for the use of colicins in areas such as the control of plant diseases of bacterial origin, and even in medical applications as preparations of colicinogenic E.coli strains commercially available under the names of MUTAFLOR ${ }^{\hat{a}}$ and SYMBIOFLOR $^{\text {a }}$ which have proved to be successful in the treatment of idiopathic chronic constipation as well as functional intestinal disorders and chronic inflammatory bowel disease $(45,52,53)$. In addition, a promising field in biotechnology is the use of bacteriocin release proteins (BRP) or lysis proteins mediating the release of a wide variety of heterologous proteins. Since expression of BRP causes the release of almost the entire periplasmic content, expression and processing of the target protein should be highly efficient to selectively enrich the culture medium with the target protein $(100,108)$. The last, but most hopeful example, is the antitumor effect of colicins that was confirmed in vitro as well as in vivo. In the future, colicins could be used against certain types of tumor such as lymphosarcoma, breast carcinoma and different colon tumors $(91,92,95,96)$.

\section{CONCLUSIONS}

The start of colicin research was not motivated by any concrete needs (34). The colicins were and are studied simply because they exist (98). They represent a special and highly successful adaptation form of environment challenge and an important source of data for the understanding of bacterial relationships, their evolution and diversity. Studies about colicins were and still are promising not only because of their possible applications, but especially to discover how complex and wonderful the bacterial universe is.

\section{RESUMO}

\section{Aspectos atuais de colicinas de Enterobacteriaceae}

As colicinas são compostos proteináceos produzidos por Escherichia coli e outros membros da família Enterobacteriaceae, sendo ativas, principalmente, contra bactérias mais relacionadas. São conhecidos pelo menos 34 tipos diferentes de colicinas, apresentando algumas delas características intrigantes. Nesta revisão são abordados os principais aspectos das colicinas das bactérias gram-negativas, explorando desde sua produção até ass suas aplicações práticas.

Palavras-chave: colicinas, Escherichia coli, genética, evolução, ecologia.

\section{REFERENCES}

1. Abbot, J.D.; Graham, J.M. Colicin typing of Shigella sonnei Moth. Bull. Minist. Health Lab. Serv., 20: 50-51, 1961.

2. Ahmer, B.M.M.; Thomas, M.G.; Larsen, R.A.; Postle, K. Characterization of the exbBD operon of Escherichia coli and role of ExbB and ExbD in TonB function and stability. J. Bacteriol., 177: 4742-4747, 1995.

3. Akutsu, A.; Masaki, H.; Ohta, T. Molecular structure and immunity specficity of colicin E6, an evolutionary intermediate between Egroup colicins and cloacin DF13. J. Bacteriol., 171: 6430-6436, 1989.

4. Baba, T.; Chneewind, O. Instruments of microbial warfare, bacteriocin synthesis, toxicity and immunity. Trends in Microbiol., 6: 66-71, 1998.

5. Bénédetti, H.; Frenette, M.; Baty, D.; Knibiehler, M.; Pattus, F.; Lazdunski, J.C. Individual domains of colicins confer specificity in colicin uptake, in pore-properties and in immunity requirements. $J$. Mol. Biol., 217: 429-439, 1991.

6. Ben-Gurion, R.; Hertman, I. Bacteriocin-like material produced by Pasteurella pestis. J. Gen. Microbiol., 19: 289-294, 1958.

7. Bradley, D.E. Colicins $\mathrm{G}$ and $\mathrm{H}$ and their host strains. Can J. Microbiol., 37: 751-757, 1991.

8. Bradley, D.E.; Howard, S.P. A new colicin that adsorbs to the outer membrane protein Tsx but is dependent on the TonB instead of the TolQ membrane transport system. J. Gen. Microbiol., 138: 27212724, 1992.

9. Brandis, H.; Šmarda, J. Bacteriocine und bacteriocinnähnliche Substanzen. Gustav Fisher Verlag, Jena, 1971.

10. Braun, V.; Pilsl, H.; Grob, P. Colicin structures, modes of action, transfer through membranes, and evolution. Arch. Microbiol., 161: 199-206, 1994 
11. Campbell, A. Evolutionary significance of accessory DNA elements in bacteria. Ann. Rev. Microbiol., 35: 55-83, 1981.

12. Cavard, D.; Oudega, B. General introduction to the secretion of bacteriocins. In: James, R., Lazdunski, C.; Pattus, F. (eds). Bacteriocins, Microcins and Lantibiotics Springer-Verlag, Berlin, 1992, pp.297-305.

13. Chak, K.F.; Kuo, W.S.; Lu, F.M.; James, R. Cloning and characterization of the ColE7 plasmid. J. Gen. Microbiol., 137: 91$100,1991$.

14. Chan, P.T.; Ohmori, H.; Tomizawa, J.; Lebowitz, J. Nucleotide sequence and gene organization of ColE1 DNA. J. Biol. Chem., 260: 8925-8935, 1985.

15. Chao, L.; Levin, B.R. Structured habitats and evolution of anticompetidor toxins in bacteria. Proc. Natl. Acad. Sci. USA, 78: 6324-6328, 1981.

16. Clowes, R.C. Colicin factors and epissomes. Genet. Res. Cambr., 4: $162-165,1963$.

17. Cole, S.T.; Saint-Joanis, B.; Pugsley, A. P. Molecular characterization of colicinE2 operon and identification of its proteins. Mol. Gen. Genet., 198: 465-472, 1985.

18. Cooper, P.C.; James, R. Two new E-colicins, E8 and E9 produced by a strain of Escherichia coli. J. Gen. Microbiol., 130: 209-215, 1984.

19. Cramer, W.A.; Lindeberg, M.; Taylor, R. The best offense is a good defense. Nat. Struct Biol., 6: 295-297, 1999.

20. Davies, J.K.; Reeves, P. Genetics of resistance to colicins in Escherichia coli K-12: cross- resistance among colicins of group B. J. Bacteriol., 123: 96-101, 1975.

21. Dekker, N.; Tommassen, J.; Verheij, H.M. Bacteriocin release protein triggers dimerization of outer membrane phospholipase A in vivo. $J$. Bacteriol., 181: 3281-3283, 1999.

22. Dobrindt, U.; Blum-Oehler, G.; Hartsch, T.; Gottschalk G.; Ron, Z.E.; Fünfstück, R.; Hacker, J.S.-fimbria-encoding determinant $s f a i$ is located on pathogenicity island III 536 of uropathogenic Escherichia coli strain 536. Infect. Immun., 69: 4248-4256, 2001.

23. Dykes, G.A. Bacteriocins: ecological and evolutionary significance. Trends Ecol. Evol., 8: 369-386, 1995.

24. Dykes, G.A.; Hastings, J.W. Selection and fitness in bacteriocinproducing bacteria. Proc. R. Soc. Lond B. Biol. Sci., 264: 683-687, 1997.

25. Farkas-Himsley H.; Cheung R. Bacterial proteinaceous products (bacteriocins) as cytotoxic agents of neoplasia. Cancer Res., 36 3561-3567, 1976.

26. Feldgarden M.; Golden, S.; Wilson, H.; Riley, M. A. Can phage defense maintain colicin plasmids in Escherichia coli?. J. Microbiol., 141: 2977-2984, 1995.

27. Foulds, J.; Shemin, D. Properties and characteristics of a bacteriocin produced by Serratia marcescens J. Bacteriol., 99: 655-660, 1969.

28. Frank, S. Spatial polymorphism of bacteriocins and other allelopathic traits. Evol. Ecol., 8: 369-386, 1994.

29. Fredericq, P. Acquisition de proprietes antibiotiques nouvelles par la souche E. Coli V sous l'action des bacteriophages T1, T5 et T7. Antonie van Leeuwenhoek J. Microbiol. Serol., 17: 102-106, 1951.

30. Fredericq, P. Actions antibiotiques réciproques chez les Enterobacteriaceae. Rev. Belge Path. Exp. Med. exp., 19: 1-107, 1948.

31. Fredericq, P. Genetics of two different mechanisms of resistance to colicins: resistance by loss of specific receptor and immunity by transfer of colicinogenic factors. Presented at Ciba Symp. Drug Resist. Microorg., Churchill, London, 1957.

32. Fredericq, P.; Betz-Bareau, M. Transfert génétique de la proprieté colicinogéne chez E. coli. Compt. Rend. Soc. Biol., 147: 11101112,1953

33. Gordon, D.M.; Riley M.A.; Pinou, T. Temporal changes in the frequency of colicinogeny in Escherichia coli from house mice. Microbiology., 144: 2233-2240, 1998.

34. Gratia, A. Sur un remarquable exemple d'antagonisme entre deux souches de colibacille. Comp. Rend. Soc. Biol., 93: 1040-1041, 1925 .
35. Guasch, J.F.; Enfedaque, E.; Ferrer, S.; Gargallo, D.; Regué, M. Bacteriocin 28b, a chromosomally encoded bacteriocin produced by most Serratia marcescens biotypes Res. microbiol., 146: 447-483, 1995.

36. Hamon, Y.; Péron, Y. A propos de quelques noveaux types de colicines thermostables. Compt. Rend. Acad. Sci., 258: 3121-3124, 1964a.

37. Hamon, Y.; Péron, Y. description de sept noveaux types de colicines. État actuel de la classification de ces antibiotiques. Ann. Inst. Pausteur. 106: 44-54, 1964b.

38. Hardy, K. Colicinogeny and related phenomena. Bacteriol. Rev., 39: 464-515, 1974

39. Hauduroy, P.; Papavassiliou, J. Identification of a new type of coline (colicine L) Nature., 195: 730-732, 1962.

40. Horák, V. Two colicins from Shigellae. Fol. Microbiol., 35: 469470, 1990.

41. Hwang, J.; Manuvakhova, M.; Tai P.C. Characterization of in-frame proteins encoded by Cvaa,an essential gene in the colicin V secretion system: CvaA*stabilizes CvaA to enhance secretion. J. Bacteriol., 179: 689-696, 1997

42. James, K.S.; Zinder, N. Highly purified colicin E3 contains immunity protein. Proc. Natl. Acad. Sci. USA, 71: 3380-3384, 1974.

43. James, R.; Jarvis, M.; Braker, D.F. Nucleotide sequence of the immunity and lysis region on the ColE9-J plasmid. J. Gen. Microbiol., 133: 1553-1562, 1987.

44. James, R.; Kleanthous, C.; Moore, G.R. The biology of E colicins: paradigms and paradoxes. Microbiology., 142: 1569-1580, 1996.

45. Jansen, G.J.; Wildeboer-Veloo, A.C.; van der Waaij, D.; Degener, J.E. Escherichia coli as a probiotic? Infection., 26: 232-233, 1998.

46. Koninsky, J.; Richards, F.M. Characterization of the colicin Ia and Ib. Purification and some physical properties. J. Biol. Chem., 245: 2972-2978, 1970.

47. Konisky, J. Colicins and others bacteriocins with established modes of action. Ann. Rev. Microbiol., 36: 125-144, 1982.

48. Lau, P.C.K.; Condie, J.A. Nucleotide sequences from the colicins E6 and E9 operons: presence of a degenerate transposon-like structure in the ColE9-J plasmid. Mol. Gen. Genet., 217: 269-277, 1989.

49. Lazdunski, C.; Bouveret, E.; Rigal, A.; Journet, L.; Lloubès, R.; Bénédetti, H. Colicin import into Escherichia coli cells. J. Bacteriol., 180: 4993-5002, 1998.

50. Lazdunski, C.; Bouveret, E.; Rigal, A.; Journet, L.; Lloubès, R.; Bénédetti, H. Colicin import into Escherichia coli cells requires the proximity of the inner membranes and others factors. Int. J. Med. Microbiol., 290: 337-344, 2000.

51. Levin, B.R. Frequency-dependent selection in bacterial population Phil. Trans. Roy Soc. Lond. B., 319: 459-472, 1988.

52. Lodinova-Zadnikova, R.; Sonnenborn U.; Tlaskalova, H. Probiotics and E. coli infections in man., Vet Q, 20: 78-81, 1998.

53. Lodinova-Zadnikova, R.; Sonnenborn, U. Effect of preventive administration of a nonpathogenic Escherichia coli strain on the colonization of the intestine with microbial pathogens in newborn infants. Biol. Neonate., 71: 224-232, 1997.

54. Lokaj, J.; Šmarda, J.; Mach, J. Colicin E3 enhances the oxireductive active of guinea-pig leukocytes. Experientia., 38: 1352-1353, 1982.

55. Lotz, W. Effect of guanosine tetraphosphate on in vitro protein synthesis directed by E1 and E3 colicinogenic factors. J. Bacteriol., 135: 707-712, 1978.

56. Lu, F.M.; Chak, K.F. Two overlapping SOS boxes in ColE1 operon are responsible for the viability of cells harboring the Col plasmid. Mol. Gen. Genet., 251: 407-411, 1996.

57. Males, B.M.; Stocker, B.A.D. Colicin E4, colicin E5, colicin E6 and colicin A and properties of btub $b^{+}$colicinogenic transconjugants. $J$. Gen. Microbiol., 128: 95-106, 1982.

58. Morell, V. Bacteria diversify through warfare. Science, 278: 575, 1997.

59. Morlon, J.; Lloublés, R.; Varenne, S.; Chartier, M.; Lazdunuski, C. Complex nucleotide sequence of the structural gene for the colicin A, a gene translated at a non-uniform rate. J. Mol. Biol., 170: 271$285,1983$. 
60. Moss, J.E.; Cardozo, T.J.; Zychlinsky, A.; Groisman, E.A. The selCassociated SHI-2 pathogenicity island of Shigella flexneri. Mol. Microbiol., 33: 74-83, 1999.

61. Murinda, E.S.; Robert, R.F.; Evaluation of colicins for inhibitory activity against diarrheagenic Escherichia coli strains including serotype O157:H7. Appl. Environ. Microbiol., 62: 3196-3202, 1996.

62. Nakamaru, M. and Iwasa, Y. Competition by allelopathy proceeds in traveling waves: colicin-immune strain aids colicin-sensitive strain. Theor Popul Biol., 57: 131-144, 2000.

63. O’Brien, G.J.; Chambers, S.T.; Peddie, B.H.; Mahanty, K. The association between colicinogenicity and pathogenesis among uropathogenic isolates of Escherichia coli. Microb Pathog., 20: 185-190, 1996

64. Ölschläger, T.; Braun, V. Sequence, expression and localization of the immunity protein for colicin M. J. Bacteriol., 169: 4765-4769, 1987

65. Ozeki, E.T.; Stocker, H.; De Margerie, B.A.D. Production of colicin by single bacteria. Nature, 184: 337-339, 1959.

66. Pilsl, H.; Braun, V. Novel colicin 10: assignment of four domains to TonB- and TolC-dependent uptake via the Tsx receptor and to pore formation. Mol. Microbiol., 16: 57-67, 1995a.

67. Pilsl, H.; Braun, V. Evidence that the immunity protein inactivates colicin 5 immediately prior formation of the transmembrane channel. J. Bacteriol., 177: 6966-6972, 1995b.

68. Pils1, H.; Braun, V. Strong function-related homology between the pore-forming colicins K and 5. J. Bacteriol., 177: 6973-7, 1995c.

69. Pils1, H.; Killmann, H.; Hantke, K.; Braun, V. Periplasmic location of the pesticin immunity protein suggest sinactivation of pesticin in the periplasm J. Bacteriol., 178: 2431-2435, 1996.

70. Postle, K. TonB protein and energy transduction between membranes. J. Bioenerg. Biomembr., 25: 591-601, 1993.

71. Pugsley, A.P. Escherichia coli K12 strains for use in the identification and characterization of colicins. J. Gen. Microbiol., 131: 369-76, 1985.

72. Pugsley, A.P. Nucleotide sequencing of the structural gene for colicin $\mathrm{N}$. reveals homology between the catalytic C-terminal domains of colicin A and colicin N. Mol. Microbiol., 1: 317-325, 1987.

73. Pugsley, A.P. The immunity and lysis genes of CoIN plasmid pCHAP4 Mol. Gen. Genet., 211: 335-341, 1988.

74. Pugsley, A.P. The ins and outs of colicins. Part I. Production, and translocation across membranes. Microbiol. Sciences, 1: 168-176, 1984a.

75. Pugsley, A.P. The ins and outs of colicins. Part II. Lethal action, immunity and ecological implications. Microbiol. Sciences, 1: 203205, 1984b.

76. Pugsley, A.P.; Schwartz, M. Colicin E2 release: lysis, leakage or secretion? Possible role of a phospholipase. EMBO J., 10: 23932397, 1984.

77. Riley, M.A. Molecular evolution of colicin. Mol. Biol. Evol., 10: 1048-1059, 1993a.

78. Riley, M.A. Molecular mechanisms of colicin evolution. Mol. Biol. Evol., 6: 1380-1395, 1993b.

79. Riley, M.A. Molecular mechanisms of bacteriocin evolution. Ann. Rev. Microbiol., 32: 255-278, 1998.

80. Riley, M.A.; Gordon, D.M. A survey of col plasmids in natural isolates of Escherichia coli and an investigation into stability of col-plasmids lineages. J. Gen. Microbiol., 138: 1345-1352, 1992.

81. Riley, M.A.; Gordon, D.M. Ecology and evolution of bacteriocins. $J$. Ind. Microbiol., 17: 155-158, 1995.

82. Riley, M.A.; Gordon, D.M. The ecology and evolution of bacteriocins J. Ind. Microbiol., 17: 151-158, 1996.

83. Riley, M.A.; Tan Y.; Wang, J. Nucleotide polymorphism in colicin E1 and Ia plasmid from natural isolates of Escherichia coli. Proc. Natl. Acad. Sci. USA, 91: 11276-11280, 1994.

84. Roos, U.; Harkness, R.E.; Braun, V. Assembly of colicin genes from a few DNA fragments. Nucleotide sequency of colicin D. Mol. Microbiol., 3: 891-902, 1989.
85. Saito, H.; Watanabe, T. Effect of a bacteriocin produced by Mycobacterium smegmatis on growth of cultured tumor and normal cells. Cancer Res., 39: 5114-5117, 1979.

86. Salles, B.; Weisemann, J.M.; Weinstock, G.M. Temporal control of colicin E1 induction. J. Bacteriol., 169: 5028-5034, 1987.

87. Schramm, E.; Mende J.; Braun, V.; Kamp, R.M. Nucleotide sequence of colicin B activity gene cba: consensus peptapeptide among TonBdependent colicins and receptors. J. Bacteriol., 169: 3350-3357, 1987.

88. Selander, R.K.; Musser, J.M.; Caugant, D.A.; Gilmour, M.N.; Whittam, T.S. Population of genetics pathogenic bacteria. Microb. Pathog., 3: 1-7, 1987.

89. Šmajs, D. The morphology of bacterial cell in inhibition zones produced by colicins. Scripta Med., 68: 171-180, 1995.

90. Śmajs, D.; Pilsl, H.; Braun, V. Colicin U a novel colicin produced by Shigella boydii J. Bacteriol., 179: 4919-4928, 1997.

91. Šmarda, J. Resistance and tolerance of bacteria to E colicins. In: James, R.; Lazdunski, C.; Pattus, F. (eds). Bacteriocins, Microcins and Lantibiotics. Springer-Verlag, Berlin, 1992, pp.493-505.

92. Šmarda, J. The action of colicins on eucaryotic cells. J. Toxicol. Toxin. Rev., 2: 1-76, 1983.

93. Šmarda, J.; Obdrzálek, V. Colicin Q Zbl. Bakt. Hyg. A I Orig., 200: $111-118,1966$

94. Šmarda, J.; Obdrzálek, V. Incidence of colicinogenic strains among human Escherichia coli. J. Basic Microbiol., 41: 367-374, 2001.

95. Šmarda, J.; Obdrzalek, V.; Taborsky, I.; Mach, J. The cytotoxic and cytocidal effect of colicin E3 on mammalian tissue cells. Fol. Microbiol., 23: 272-277, 1978.

96. Šmarda, J.; Oravec, C. In vitro and in vivo inhibition of blast lymphocytes by colicins. Fol. Microbiol., 38: 120-121, 1993.

97. Smarda, J.; Petrzelová, J.; Vyskot, B. Colicin Js of Shigella sonnei: calssification of type colicin "7". Zbl. Bakt. Hyg. A I Orig., 263: 530-540, 1987

98. Šmarda, J.; Šmajs, D. Colicins: exocellular lethal proteins of Escherichia coli. Fol. Microbiol., 43: 563-582, 1998.

99. Spangler, R.; Zhang, S.; Krueger, J.; Zubay, G. Colicins synthesis and cell death. J. Bacteriol., 163: 167-173, 1985.

100.Steidler, L.; Fiers, W.; Remaut, E.S. Efficient specific release of periplasmatic proteins from Escherichia coli using temperature induction of cloned kill gene of pMB9. Biotechnol. Bioeng., 44: 1074-1082, 1994.

101. Stouthamer, A.H.; Tietze, G.A. Bacteriocin production by members of the genus Klebsiella. Antonie van Leeuwenhoek J. Microbiol. Serol., 32: 171-182, 1966.

102. Tan, Y.; Riley, M.A. Nucleotide polymorphism in colicin E2 gene clusters; evidence for nonneutral evoultion. Mol. Biol. Evol., 14: 666-673, 1997

103.Tan, Y.; Riley, M.A. Rapid invasion of colicinogenic bacteria with novel immunity function. Microbiology., 142: 2175-2180, 1995.

104. Toba, M.; Masaki, H.; Otha,T. Colicin E8 a DNase which indicates an evolutionary relationship between colicins E2 and E3. J. Bacteriol., 170: 3237-3242, 1988.

105.van den Elzen, P.J.M.; Walters, H.H.B.; Veltkamp, E.; Nijkamp, H.J. Molecular structure and function of the bacteriocin gene and bacteriocin protein of the plasmid cloDF13. Nucl. Acids Res., 11: 2465-2477, 1983.

106. Vianney, A.; Lewin, T.M.; Beyer Jr., W.F.; Lazzaroni, J.C.; Portalier, R.; Webster, R.E. Membrane topology and mutational analysis of the TolQ protein of Escherichia coli required for the uptake of macromolecules and cell envelope integrity. J. Bacteriol., 176: 822829, 1996.

107. Viejo, M.B.; Gargallo, D.; Ferrer, S.; Enfedaque, J.; Regué, M. Colining and DNA sequence analysis of a bacteriocin gene from Serratia marcescens. J. Gen. Microbiol., 138: 1737-1743, 1992.

108. Wan Der Wal, F.; Luirink, J.; Oudega, B. Bacteriocin release proteins: mode of action, structure, and biotechnological application. FEMS Microbiol. Rev., 17: 381-399, 1995.

109. Waters, V.L.; Croza, J.H. Colicins V virulence plasmid. Microbiol. Rev., 55: 437-450, 1991 
110. Whelan, K.F.; Colleran E.; Taylor, D.E. Phage inhibition, colicin resistance, and tellurite resistance are encoded by a single cluster of genes on the IncH12 plasmid R478. J. Bacteriol., 177: 5016-5027, 1995.

111. Wooley, R.E.; Nolan, L.K.; Brown J.; Gibbs, P.S.; Bounous, D.I.;

Phenotypic expression of recombinant plasmids pKT107 and pHK11 in an avirulent avian Escherichia coli. Avian. Dis., 38: 127-34, 1994.

112.Zinder, N.D. Resistance of colicins E1and $\mathrm{K}$ induced by infection of bacteriophage f1. Proc. Natl. Acad. Sci. USA, 70: 3160-3164, 1973. 